\title{
IAMJ
}

INTERNATIONAL

AYURVEDIC

MEDICAL JOURNAL

ISSN: 2320-5091

Impact Factor: 6.719

\section{A SCIENTIFIC REVIEW ON THE CONCEPT OF SHATKRIYAKAL IN AYURVEDA}

\section{Sakshi Bakshi}

M.D. Kayachikitsa, Assistant Professor, Department of Rog Nidan \& Vikruti Vigyan.

Ishan Ayurvedic Medical College and Research Centre, Greater Noida, Uttar Pradesh, India

Corresponding Author: drsakshibakshi03@gmail.com

https://doi.org/10.46607/iamj3308122020

(Published online: December 2020)

Open Access

(C) International Ayurvedic Medical Journal, India 2020

Article Received: 14/12/2020 - Peer Reviewed: 15/12/2020 - Accepted for Publication: 16/12/2020

Check for updates

\section{ABSTRACT}

Ayurveda has principle of maintenance of health and curation of disease, for that purpose it has given the very beautiful explanation of Dinchariya and Rutuchariya to have a healthy life and Acharya Sushruta has given the important concept of 'Shatkriyakala' to understand the stages of disease and Doshaawastha to apply the correct treatment on correct time as treatment is changes according to stage of disease. Early diagnosis of the stages of the disease will help to cure the disease more successfully with the planned management. Shatkriyakala described by Sushruta gives an idea about the consecutive stages of the disease and accordingly preventive measures were described to overcome complication. For the control and prevention of the disease, guidelines like Dinchariya and Rutuchariya must be adopted. Along with these concepts, knowledge of Shatkriyakala plays an important role in prevention as well as management of the disease

Keywords: Ayurveda, Doshas, Shatkriyakala, Dinchariya, Rutuchariya

\section{INTRODUCTION}

Samaawastha of Tridosha provide the Arogya and their Vruddhi and Kshaya causes the disease. ${ }^{1}$ Differentiation of the disease according to the Dosha is necessary which is obtain by applying
Tridosha Siddhanta to Sushrutoktshatkriya Kala. One who knows the Sanchaya, Prakopa, Prasar, Sthansanshraya, Vyakti, and Bheda is only the real Chikitsak. In modern science a disease is manifested 
mainly in two steps, one in which disease is present with its specific sign symptoms and the other in which complication of the disease come into the sight. On other hand Ayurveda describes the disease into six stages (Shatkriya Kala). Shatkriyakala described by Sushruta gives an idea about the consecutive stages of the disease and accordingly preventive measures were described to overcome complication. Early diagnosis of disease helps to cure the disease successfully without much discomfort in planning treatment. If physician able to detect the changes in early stages like Sanchaya (accumulation), Prakop etc. based on the manifestation of Dosha symptomatology and advise the techniques at that stage to prevent further stages, so that disease may not become stronger Shatakriyakala is the process of understanding the pathogenesis of disease in consecutive stages. Mainly 6 stages are described for the successive manifestation of the disease as following. ${ }^{2}$

1) Sanchaya; 2) Prakopa; 3) Prasara; 4) Sthanasamshraya; 5) Vyaktavastha; 6) Bhedavastha

Objective: To review Scientific Concept of Shatkriyakal in Ayurveda.

\section{Materials and Methods}

Sushruta Samhita, Ashtang Hridaya and Ayurveda Vikruti Vidnyana and Rog Vidnyana books were used and reviewed.

\section{Conceptual Study}

\subsection{Chaya $^{3}$ (Accumulation)}

Due to causative factors, Doshas increase in their own places. This is the first stage called Chaya.

Vatasanchaya: Stabdhapurnakoshtata i.e. hardness or rigidity of intestine or hollow spaces of abdomen and feeling of fullness inside them (hyperperistalsis of intestine).

Pitta Sanchaya: Peetavabhasta i.e. yellowish tinges of the skin.

Kaphasanchaya: Mandushmata i.e. low temperature, Gaurava i.e. feeling of heaviness in the body and Alasya i.e. laziness.

\subsection{Prakopa (Aggravation)}

Causes of Vata Prakopa ${ }^{4}$

- Qualities: dryness, irritant, cold, lightness etc.
- Tastes: astringent, bitter, pungent, Amla, Tikta, Kashay.

- Food: dry vegetables, dry fish, desert animal meat.

- Activities: excessive exercise, malnutrition, injury, fracture, muscle wasting, skipping night sleep, suppression of natural urges, excess sexual indulgence.

- Natural causes: cold season, cloudy day, at the end of digestion, later part of the day, rainy season, end part of the night.

\section{Causes of Pitta Prakop}

- Qualities: hotness, corrosive, irritant.

- Taste: Katu, Amla, Lavan, pungent, sour, salt.

- Food: spicy food, sesame, sour curds, alcohol, sour food and drinks.

- Activities: excessive exposure to sun or fire, anger, excess fasting excess sexual indulgence.

- Natural causes: During digestion, mid-day, autumn season, midnight.

Causes for Kapha Prakop ${ }^{6}$

- Qualities: Stabdhta (heaviness), Sheetata (coldness), liquidity, oiliness.

- Tastes: sweet, sour, salt (Madhur-Amla-Lavan).

- Food: oily food, fried food, milk and its products, sugarcane and its products, sweet-high calorie food, meet with ghee.

- Activities: lack of exercise, sedentary lifestyle, over nutrition, day sleeping.

- Natural causes: immediately after food, early in the morning, spring season, early hours of night.

\section{Prakopa lakshanas ${ }^{7}$}

- Symptoms of Vata Prakop: Koshtatoda (pricking sensation in abdomen), Koshtasancharna (sound in the abdomen).

- Symptoms of Pitta Prakop: Amlika (heart burn), Pipasa (thirst), Paridaha (burning sensation).

- Symptoms of Kaphaprakop: Annadwesh, Hrudayautklesh.

\subsection{Prasara $^{8}$ (Overflow)}

As fermentation occurs when flour and water is mixed and kept for a night, in the same manner Prakupit Doshas cause the Prasaravastha and only vayu is responsible for that because of 
the Rajobahul as raja is Pravartaka in nature. Doshas are mixed as only single or with two or with three or they mixed with Raktadosha according to Acharya Sushruta. (Being a surgeon, he mentioned Rakta as fourth Dosha.) Doshas show the 15 types of mixing. The principle of treatment at this stage is to correct the Ashaya (organ) into which unconcerned Doshas have entered. ${ }^{9}$

\subsection{Sthana Sanshraya ${ }^{10}$ (Localization)}

The stage of lodging in of vitiated doshas, give origin to premonitory symptoms of disease. Sthana means place or site Samshraya means to get lodge. The circulating Doshas get lodged in a weak tissue or organ. Dosha is the one which afflicts Dushya i.e. the one which get affected. Dosha afflicts tissues (dhatu) and waste products (mala) to cause disease. Hence Dushya are tissue and waste product. The amalgamation between Doshas with tissue and waste product is called Doshadushyasammurchana. On localization the vitiated Doshas slowly start damaging the host tissue and cause the disease pertaining to that tissue or organ. The mechanism of their localization is like a wandering cloud when obstructed by a mountain rain is spotted where it gets obstructed. ${ }^{11}$ Dosh Dushyasammurchna leads to formation of early symptoms of disease. It is weak in early stage; hence symptoms are also weak. These symptoms of the future disease are called Purvaroop as there for the fourth stage is also called the Purvaroopawastha or stage of early symptoms.

\subsection{Vyakti ${ }^{12}$ (Manifestation)}

The stage of manifestation of disease with sign and symptoms. In this stage Doshas have gotten stubbily lodged deeper into the tissues. The sign and symptoms are clearly manifested and denote the disease. Therefore, this stage is also called Rupaawastha. The disease is named in this stage. The treatment in this stage is either by symptoms specific or disease specific. If this disease is neglected at this stage it gets entered the last stage.

\subsection{Bheda ${ }^{13}$ (Differentiation)}

The stage of manifestation of complications. At this stage treatment needed is very aggressive as Doshas are well manifested in the diseased condi- tion. If this stage is also neglected the disease becomes Asadhya.

\section{DISCUSSION}

Shatkriyakala assures a more accurate management of the disease with various suitable drugs. The progress of the disease can be come under control by preventing further consumption of the Hetusevan. The knowledge of the Sthanasamshraya may protect the organ which may get affected in the future. Depending upon the stage of shatkriyakala sadhyaasadhya of the disease may revealed. Knowledge of Shatkriyakala may assist in deciding the prognosis of the disease. In present era, modern lifestyle has become the root cause of for many diseases. Tight schedule, pressure-oriented jobs, disturbed sleeping habit and incompatible food have become one of the leading causes of disease. So, for control and prevention of the disease, guidelines like Dinchariya and Rutuchariya must be adopted. Along with these concepts, knowledge of Shatkriyakala plays an important role in prevention as well as management of the disease.

\section{CONCLUSION}

This concept is universally true for all disorders. It is very beneficial for a physician for making diagnosis of the disease and it helps for further prognosis of the disease. It is also helpful in interrupting the Sadhyaasadhyatva of the diseases and has the significant role in management of various diseases. As we all know that prevention is better than cure, it is need of the era to follow the guidelines as mentioned in the ancient texts like Ayurveda.

\section{REFERENCES}

1. Gupta Atridev Editor. ( $1^{\text {st }}$ ed.). Commentary of Hemadri on Ashtaang Hrudaya of Vabhata, Sutrasthaan: Ayushkamiya Adhyay, Chapter 1, Verse 19. Varanasi: Chaukhaba Sanskrit Sansthan 2014; p. 12.

2. Kaviraj Ambika Dutta Shastri Editor. (Reprint ed.). Sushruta Samhita of Sushruta, Sutrasthaan: Vranaprashniya Adhyay, Chapter 21, Verse 36. Varanasi: Kashi Sanskrit Series. p. 94. 
3. Prof. V V Prasad Editor. (Reprint ed.). Nibandhasangraha Commentary of Dalhan on Sushruta Samhita of Sushruta, Sutrasthaan: Ayushkamiya Adhyay, Chapter 21, Verse 8. New Delhi: Rashtriya Ayurved Vidyapeet 2002; p. 224.

4. Ibidem 2, Sutrasthana, Chapter 21, Verse 19.p. 91.

5. Ibidem 2, Sutrasthana, Chapter 21, Verse 22. p. 91.

6. Ibidem 2, Sutrasthana, Chapter 21, Verse 23. p. 91.

7. Ibidem 3, Sutrasthana, Chapter 21, Verse 27. p. 227.

8. Ibidem 3, Sutrasthana, Chapter 21, Verse 28. p. 227.

9. Ibidem 3, Sutrasthana, Chapter 21, Verse 32. p. 229.

10. Ibidem 2, Sutrasthana, Chapter 21, Verse 33. p. 93.

11. Ibidem 2, Sutrasthana, Chapter 21, Verse 34. p. 93.

12. Ibidem 2, Sutrasthana, Chapter 21, Verse 23. p. 91.

13. Ibidem 3, Sutrasthana, Chapter 21, Verse 35. p. 230.

\section{Source of Support: Nil}

\section{Conflict of Interest: None Declared}

How to cite this URL: Sakshi Bakshi: A Scientific Review On The Concept Of Shatkriyakal In Ayurveda. International Ayurvedic Medical Journal \{online\} 2020 \{cited December, 2020\} Available from: http://www.iamj.in/posts/images/upload/5391_5394.pdf 